\title{
SISTEM PENDUKUNG KEPUTUSAN MAHASISWA BERPRESTASI MENGGUNAKAN METODE KOMBINASI ANALYTICAL HIERARCHY PROCESS (AHP) DAN SIMPLE ADDITIVE WEIGTING (SAW)
}

\author{
Lukas Arief Prasetyo \\ Program Studi Informatika, Universitas Indraprasta PGRI \\ Lukasariefprasetyo@gmail.com
}

\begin{abstract}
Abstrak
Pemilihan mahasiswa berprestasi di Akademi Sekretari Budi Luhur selama ini dilakukan mulai dari pengumpulan nilai-nilai yang melibatkan dosen dan staff. Berdasarkan data-data yang diperoleh, maka akan diberikan kepada Ketua Program Studi untuk dilakukan pemilihan. Cara tersebut masih kurang efektif karena dilakukan dengan perhitungan manual dan terdapat ketidakobjektifan terhadap penilaian mahasiswa dimana nilai yang diberikan dosen dan staff hanya memperkirakan dan sesuai kedekatan dengan mahasiswa saja. Ketua Program Studi membutuhkan waktu yang cukup lama untuk mengambil keputusan. Analytical Hierarchy Process (AHP) dan Simple Additive Weighting (SAW) adalah metode yang dapat digunakan untuk melakukan pemilihan mahasiswa berprestasi berdasarkan kriteria-kriteria yang ditentukan sesuai pedoman Dikti, 2016. Dimana metode Analytical Hierarchy Process (AHP) yang akan digunakan dalam pembobotan dan metode Simple Additive Weighting (SAW) yang akan digunakan dalam perangkingan. Berdasarkan dari perhitungan pembobotan dan perangkingan tersebut diharapkan dapat membuat aplikasi sistem pendukung keputusan yang efektif dan objektif.
\end{abstract}

Kata Kunci : Sistem Pendukung Keputusan, Analytical Hierarchy Process (AHP), Simple Additive Weighting (SAW), Mahasiswa Berprestasi

\begin{abstract}
The selection of outstanding students at Secretary Academy of Budi Luhur has long been conducted from the collection of scores involving lecturers and staff. The collected data are then given to the Head of Study Program for the selection. The method is considered less effective because it uses manual calculation and shows no objectivity in the student assessment in which the scores given by lecturers and staff are only based on their estimation and closeness to students. The Head of the Study Program takes a long time to make a decision. Analytical Hierarchy Process (AHP) and Simple Additive Weighting (SAW) are methods that can be used to select outstanding students based on the criteria set in Dikti guidelines 2016. The Analytical Hierarchy Process (AHP) is used in weighting process, while the Simple Additive Weighting (SAW) is used in ranking process. It is expected that the weighting and ranking processes can create an effective and objective decision support system application.
\end{abstract}

Keywords: Decision Support System, Analytical Hierarchy Process (AHP), Simple Additive Weighting (SAW), Outstanding Student

\section{PENDAHULUAN}

Dalam era persaingan bebas dibutuhkan lulusan yang memiliki hard skills dan softs kills yang seimbang [1]. Oleh karena itu Akademi Sekretari Budi Luhur perlu melakukan identifikasi mahasiswa yang berprestasi di kedua kompetensi itu dan yang terbaik perlu diberi penghargaan sebagai mahasiswa yang berprestasi (Mawapres). Akademi Sekretari Budi Luhur di akhir semester selalu melakukan pemilihan mahasiswa berprestasi untuk 
tiap angkatan. Saat ini dalam menentukan mahasiswa berprestasi selalu menemui permasalahan. Pemilihan mahasiswa berprestasi di Akademi Sekretari Budi Luhur saat ini dilakukan belum objektif yaitu mulai dari pengumpulan nilai-nilai yang melibatkan dosen dan staff. Berdasarkan data-data yang diperoleh, maka akan diberikan kepada Ketua Program Studi untuk dilakukan pemilihan. Cara tersebut masih kurang efektif karena dilakukan dengan perhitungan manual dan terdapat ketidakobjektifan terhadap penilaian mahasiswa dimana nilai yang diberikan dosen dan staff hanya memperkirakan dan sesuai kedekatan dengan mahasiswa saja, sehingga terkadang hasilnya tidak akurat, selain itu tidak ada aplikasi yang mendukung pengambilan keputusan data menentukan mahasiswa berprestasi, Ketua Program Studi membutuhkan waktu yang cukup lama untuk mengambil keputusan. Oleh karena itu untuk memudahkan pemilihan mahasiswa berprestasi perlu dibuat suatu sistem yang mampu memberikan hasil pemenang mahasiswa berprestasi dan mempermudahkan proses pemilihan mahasiswa berprestasi. Untuk itu, diperlukan suatu Sistem Pendukung Keputusan (SPK) yang penyelesaian masalahnya menggunakan metode kombinasi Analytical Hierarchy Process (AHP) dan Simple Additive Weighting (SAW) yang dapat memperhitungkan segala kriteria yang mendukung pengambilan keputusan pemilihan mahasiswa secara objektif dan mudah dalam proses melakukan perangkingan untuk menentukan mahasiswa berprestasi.

\section{METODE PENELITIAN}

Penelitian tahap awal berdasarkan datadata yang telah diperoleh melalui tahapan wawancara, observasi dan studi pustaka untuk mendapatkan kebutuhan-kebutuhan sistem yang akan digunakan untuk mencari solusi dalam masalah yang tepat. Sumber data yang telah diperoleh kemudian diolah secara rinci dan dikembangkan dengan bantuan metode-metode yang telah dipilih oleh peneliti guna membantu perancangan sistem yang diinginkan. Teknik analisis data yang digunakan adalah deskriptif kuantitatif. Proses penentuan prioritas menggunakan metode AHP dimulai dari perumusan masalah yaitu proses untuk menentukan kriteria dan alternatif dari penyeleksian [4]. Dalam menganalisa mahasiswa berprestasi maka digunakan kriteria-kriteria yang disesuikan dengan pedoman Dikti 2016.

Tabel 1. Kriteria-Kriteria Dalam

Pemilihan Mahasiswa Berprestasi

\begin{tabular}{|c|c|c|}
\hline No & Kriteria & Keterangan \\
\hline 1 & IPK & $\geq 3.00$ \\
\hline 2 & $\begin{array}{l}\text { Prestasi } \\
\text { Akademik }\end{array}$ & $\begin{array}{l}\text { Banyaknya sertifikat yang } \\
\text { dikumpulkan (minat bakat, } \\
\text { pengabdian masyarakat, } \\
\text { prestasi akademik) }\end{array}$ \\
\hline 3 & Bahasa Inggris & Nilai Bahasa Inggris $\geq B$ \\
\hline 4 & Kepribadian & Nilai Interpersonal skill $\geq \mathrm{B}$ \\
\hline
\end{tabular}

Untuk menentukan bobot masing-masing kriteria digunaan metode AHP, berikut adalah gambar struktur hirarki dari SPK dalam memilih mahasiswa berprestasi :

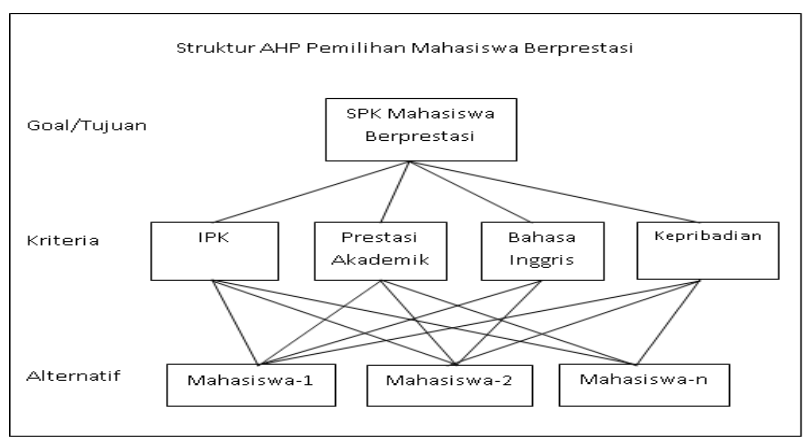

\section{Gambar 1. Struktur Hirarki Pemilihan Mahasiswa Berprestasi}

Jika proses dekomposisi telah selesai dan hirarki telah tersusun dengan baik maka dapat dilakukan penilaian perbandingan berpasangan (pembobotan) pada tiap-tiap hirarki berdasarkan tingkat kepentingan relatifnya. Penilaian atau pembobotan, 
dimaksudkan untuk membandingkan nilai atau karakter pilihan berdasarkan tiap kriteria yang ada. Misalnya antara pilihan 1 dan pilihan 2, pada kriteria 1, lebih penting pilihan 1, selajutnya antara 1 dan pilihan 3 , lebih penting pilihan 3 dan seterusnya hingga semua pilihan akan dibandingkan satu-persatu (secara berpasangan). Hasil dari penilaian adalah nilai/bobot yang merupakan karakter dari masing-masing alternatif. Sehingga nantinya akan diperoleh pembobotan tingkat kepetingan masing-masing kriteria untuk mencapai tujuan yang telah ditetapkan. Prosedur penilaian perbandingan berpasangan dalam AHP mengacu pada skor penilaian sebagai berikut [3] :

\section{Tabel 2. Perbandingan Berpasangan}

\begin{tabular}{|c|c|c|}
\hline $\begin{array}{l}\text { Nilai } \\
\text { Skala }\end{array}$ & Definisi & Penjelasan \\
\hline 1 & $\begin{array}{l}\text { Kedua elemen sama } \\
\text { pentingnya }\end{array}$ & $\begin{array}{l}\text { Dua elemen menyumbang } \\
\text { sama besar pada sifat itu }\end{array}$ \\
\hline 3 & $\begin{array}{l}\text { Elemen yang satu } \\
\text { sedikit lebih penting } \\
\text { dibandingkan } \\
\text { dengan elemen yang } \\
\text { lainnya }\end{array}$ & $\begin{array}{l}\text { Pengalaman dan } \\
\text { pertimbangan sedikit } \\
\text { menyokong satu elemen } \\
\text { atas elemen yang lainnya }\end{array}$ \\
\hline 5 & $\begin{array}{l}\text { Elemen yang satu } \\
\text { sangat penting } \\
\text { dibandingkan } \\
\text { dengan elemen yang } \\
\text { lainnya }\end{array}$ & $\begin{array}{l}\text { Pengalaman dan } \\
\text { pertimbangan sedikit lebih } \\
\text { banyak menyokong satu } \\
\text { elemen atas elemen yang } \\
\text { lainnya }\end{array}$ \\
\hline 7 & $\begin{array}{l}\text { Elemen yang satu } \\
\text { jelas lebih penting } \\
\text { dibandingkan } \\
\text { dengan elemen yang } \\
\text { lainnya }\end{array}$ & $\begin{array}{l}\text { Satu elemen dengan kuat } \\
\text { disokong dan dominannya } \\
\text { tidak terlihat dalam praktik }\end{array}$ \\
\hline 9 & $\begin{array}{l}\text { Elemen yang satu } \\
\text { mutlak lebih } \\
\text { penting } \\
\text { dibandingkan } \\
\text { dengan elemen yang } \\
\text { lainnya }\end{array}$ & $\begin{array}{l}\text { Yang menyokong elemen } \\
\text { yang satu atas yang lain } \\
\text { memiliki tingkat penegasan } \\
\text { tertinggi yang dapat } \\
\text { menguatkan }\end{array}$ \\
\hline $\begin{array}{c}2,4,6 \\
8\end{array}$ & $\begin{array}{lr}\text { Nilai antar dua } \\
\text { pertimbangan } & \text { yang } \\
\text { berdekatan } & \text { (nilai } \\
\text { ragu-ragu) } & \end{array}$ & $\begin{array}{l}\text { Kompromi diperlukan } \\
\text { antara dua pertimbangan }\end{array}$ \\
\hline $\begin{array}{c}\text { Kebali } \\
\text { kan }\end{array}$ & & \\
\hline
\end{tabular}

Setelah hirarki ditentukan, selanjutnya perangkingan dalam memilih mahasiswa berprestasi dengan metode SAW yang nilai variabel nya adalah nilai riil dari masingmasing kriteria yang telah ditentukan. Konsep dasar metode SAW adalah mencari penjumlahan terbobot dari rating kinerja pada setiap alternatif pada semua atribut. Metode SAW membutuhkan proses normalisasi matrik keputusan (X) ke suatu skala yang dapat diperbandingkan dengan semua rating alternatif yang ada. Formula

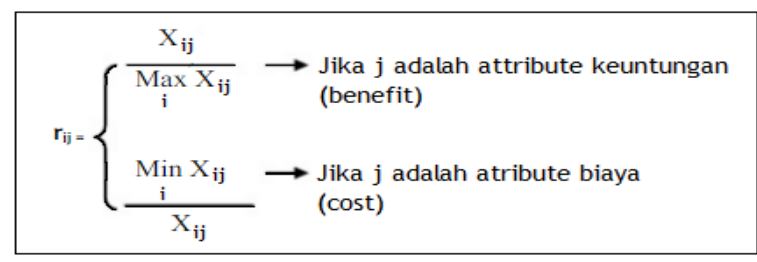

untuk melakukan normalisasi tersebut adalah sebagai berikut [2] :

Rij = Nilai rating kinerja

$\mathrm{Xij} \quad=$ Nilai kinerja dari setiap rating Max xij= Nilai terbesar dari tiap kriteria Min $x i j=$ Nilai terkecil dari tiap kriteri

Empat kriteria yang sudah ditetapkan dibagi menjadi 2 kategori yaitu :

1. Benefit (keuntungan), dimana semakin besar nilai benefitnya maka semakin tinggi peluang untuk dipilih sebagai mahasiswa berprestasi.

2. Cost (biaya), dimana semakin besar nilai cost maka semakin rendah peluang untuk dipilih sebagai mahasiswa berprestasi.

\section{Tabel 3. Kategori Benefit Dan Cost Mahasiswa Berprestasi}

\begin{tabular}{|c|c|c|c|}
\hline No & Kriteria & Kategori & Keterangan \\
\hline 1 & IPK & + & $\begin{array}{l}\text { Semakin tinggi IPK, } \\
\text { semakin besar peluang }\end{array}$ \\
\hline 2 & $\begin{array}{c}\text { Prestasi } \\
\text { Akademik }\end{array}$ & + & $\begin{array}{l}\text { Semakin tinggi } \\
\text { Prestasi Akademik, } \\
\text { semakin besar peluang }\end{array}$ \\
\hline 3 & $\begin{array}{l}\text { Bahasa } \\
\text { Inggris }\end{array}$ & + & $\begin{array}{l}\text { Semakin tinggi Bahasa } \\
\text { Inggris, semakin besar } \\
\text { peluang }\end{array}$ \\
\hline 4 & $\begin{array}{c}\text { Kepribadia } \\
\mathrm{n}\end{array}$ & + & $\begin{array}{l}\text { Semakin tinggi } \\
\text { Kepribadian, semakin } \\
\text { besar peluang }\end{array}$ \\
\hline
\end{tabular}


Dalam tahapan analisis data ini dilakukan beberapa kali sehingga hasil/output sesuai yang diharapkan. Pada dekomposisi variabel/kriteria dan nilai kategori diatas dapat katerkaitan antara kriteria sehingga hasil pembobotan kriteria menjadi lebih objektif dan sesuai dengan keadaan. Dan metode SAW untuk menghilangkan banyak langkah perbandingan berpasangan yang harus dilakukan di solusi AHP dan memberikan hasil penilaian dalam waktu yang lebih singkat.

\section{HASIL DAN PEMBAHASAN}

\section{Perhitungan Bobot Kriteria} Mahasiswa Berprestasi Metode AHP Proses perhitungan AHP dilakukan untuk mendapatkan nilai bobot prioritas dari kriteria-kriteria yang ada pada penyeleksian pemilihan mahasiswa berprestasi, berikut langkah-langkah yang dilakukan dalam melakukan proses perhitungan AHP :

A. Menghitung bobot kriteria penyeleksian pemilihan mahasiswa berprestasi, dengan cara sebagai berikut :

1. Elemen $a[i, j]=1$, dimulai $\mathrm{i}=$ $1,2,3, \ldots . n$. Untuk penilitian ini $\mathrm{n}=$ 4.

2. Elemen matriks segi tiga atas sebagai input. Pada tahap ini dilakukan penelitian perbandingan antara satu kriteria dengan kriteria yang lain. Hasil penelitian yang diperoleh dari kuisioner AHP dapat dilihat pada Tabel 4.

Tabel 4. Perbandingan Berpasangan Kriteria Mahasiswa Berprestasi

\begin{tabular}{llccc}
\hline Kriteria & $\begin{array}{l}\mathrm{IP} \\
\mathrm{K}\end{array}$ & $\begin{array}{l}\text { Prestasi } \\
\text { Akademi } \\
\mathrm{k}\end{array}$ & $\begin{array}{l}\text { Bahas } \\
\mathrm{a} \\
\text { Inggris }\end{array}$ & $\begin{array}{l}\text { Kepribadia } \\
\mathrm{n}\end{array}$ \\
\hline $\begin{array}{l}\text { IPK } \\
\begin{array}{l}\text { Prestasi } \\
\text { Akademik }\end{array}\end{array}$ & $1 / 1$ & $1 / 3$ & $1 / 5$ & $1 / 5$ \\
$\begin{array}{l}\text { Bahasa } \\
\text { Inggris }\end{array}$ & $5 / 1$ & $2 / 1$ & $1 / 1$ & $1 / 2$ \\
$\begin{array}{l}\text { Kepribadia } \\
\mathrm{n}\end{array}$ & $5 / 1$ & $2 / 1$ & $2 / 1$ & $1 / 1$ \\
\hline
\end{tabular}

B. Selanjutnya melakukan normalisasi dengan cara membagi setiap elemen dengan jumlah masing-masing kolom, seperti terlihat pada Tabel 5.

\begin{tabular}{|c|c|c|c|c|}
\hline & IPK & $\begin{array}{l}\text { Prestasi } \\
\text { Akademik }\end{array}$ & $\begin{array}{l}\text { Bahasa } \\
\text { Inggris }\end{array}$ & $\begin{array}{l}\text { Kepriba } \\
\text { dian }\end{array}$ \\
\hline IPK & 1 & 0,3333 & 0,2 & 0,2 \\
\hline $\begin{array}{l}\text { Prestasi } \\
\text { Akademik }\end{array}$ & 3 & 1 & 0,5 & 0,5 \\
\hline $\begin{array}{l}\text { Bahasa } \\
\text { Inggris }\end{array}$ & 5 & 2 & 1 & 0,5 \\
\hline Kepribadian & 5 & 2 & 2 & 1 \\
\hline Jumlah & 14 & 5,3333 & 3,70 & 2,20 \\
\hline
\end{tabular}

Tabel 6. Matrik Normalisasi Kriteria Mahasiswa Berprestasi

\begin{tabular}{lcccc} 
Kriteria & IPK & $\begin{array}{l}\text { Prestasi } \\
\text { Akademik }\end{array}$ & $\begin{array}{l}\text { Bahasa } \\
\text { Inggris }\end{array}$ & $\begin{array}{l}\text { Kepribadi } \\
\text { an }\end{array}$ \\
\hline $\begin{array}{l}\text { IPK } \\
\begin{array}{l}\text { Prestasi } \\
\text { Akademik }\end{array}\end{array}$ & 0,07 & 0,06 & 0,05 & 0,09 \\
$\begin{array}{l}\text { Bahasa } \\
\text { Inggris }\end{array}$ & 0,3571 & 0,375 & 0,2702 & 0,2272 \\
Kepribadian & 0,3571 & 0,375 & 0,5405 & 0,4545 \\
\hline
\end{tabular}

C. Cari rata-rata setiap kriteria, dengan cara jumlahkan tiap baris kemudian dibagi dengan jumlah kriteria yang ada.

Tabel 7. Tabel Rata-Rata Setiap Kriteria (Vektor Bobot)

\begin{tabular}{lccccc}
\hline & & \multicolumn{4}{c}{ Bahas } \\
Kriteria & IPK & $\begin{array}{l}\text { Prestasi } \\
\text { Akademik }\end{array}$ & $\begin{array}{l}\text { a } \\
\text { Inggri } \\
\text { s }\end{array}$ & $\begin{array}{l}\text { Kepri } \\
\text { badian }\end{array}$ & $\begin{array}{l}\text { Rata- } \\
\text { Rata }\end{array}$ \\
\hline $\begin{array}{l}\text { IPK } \\
\begin{array}{l}\text { Prestasi } \\
\text { Akademik }\end{array}\end{array}$ & 0,07 & 0,06 & 0,05 & 0,09 & 0,07 \\
$\begin{array}{l}\text { Bahasa } \\
\text { Inggris }\end{array}$ & 0,21 & 0,18 & 0,13 & 0,22 & 0,19 \\
$\begin{array}{l}\text { Kepribadi } \\
\text { an }\end{array}$ & 0,35 & 0,375 & 0,27 & 0,22 & 0,31 \\
\hline
\end{tabular}

Sehingga diperoleh vektor bobot yang dibulatkan sebagai berikut : 


$\begin{array}{ll}\quad \text { IPK } & =0,07 \\ \text { Prestasi Akademik } & =0,19 \\ \text { Bahasa Inggris } & =0,31 \\ \text { Kepribadian } & =0,43\end{array}$

2. Pengujian Perhitungan Mahasiswa Berprestasi Metode AHP

Pengujian perhitungan metode AHP dilakukan dengan cara menghitung nilai Consistency Index (CI) dan Nilai Consistency Ratio (CR) sebagai berikut:

A. Perhitungan Consistensy Index (CI) Pengukuran ini dimaksudkan agar dapat diketahui konsistensi jawaban yang akan berpengaruh kepada kesalahan hasil Rumus CI adalah :

$$
C I=\frac{\lambda \max -n}{n-1}
$$

Untuk mengetahui CI dengan besaran tertentu cukup baik atau tidak, maka perlu diketahui Consistency Ratio (CR) yang dianggap baik, yaitu apabila $\mathrm{CR}<$ 0,1, sedangkan rumus CR adalah :

$$
C R=\frac{C I}{R I}
$$

B. Perhitungan Consistency Ratio (CR) Consistency Ratio merupakan parameter yang digunakan untuk memeriksa perbandingan berpasangan telah dilakukan dengan konsekuen atau tidak [3]. Penentuan parameter ini dalam kasus kriteria pemilihan mahasiswa berprestasi dilakukan dengan proses sebagai berikut :

1. Mengalikan nilai bilangan desimal dari setiap matrik kriteria dengan vektor bobot
Tabel 8. Tabel Perkalian Kriteria dengan Vektor Bobot

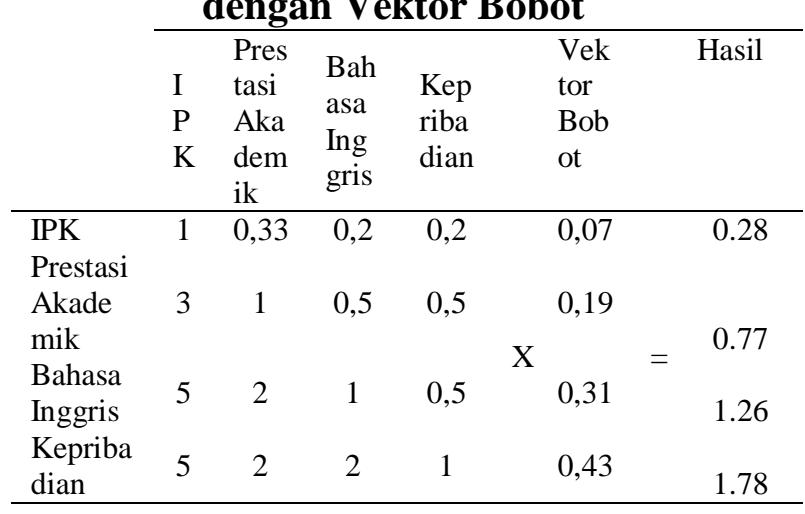

2. Menghitung Consitency Vektor dengan jalan menentukan nilai ratarata dari Weidhted Sum Vektor sebagai berikut :
$0,28: 0,07=4,0190$
$0,77: 0,19=4,0526$
$1,26: 0,31=4,0483$
$1,78: 0,43=4,1395$

3. Menghitung nilai rata-rata dari Consistency Vektor sebagai berikut:

$(4,0190+4,0526+4,0483+4,1395)$

$$
0,0649
$$

4. Menghitung nilai Consistency Index dengan menggunakan rumus sebagi berikut :

$$
\begin{aligned}
& \mathrm{CI}=\frac{(\pi-\mathrm{n})}{n-1} \\
& \mathrm{CI}=\frac{(4,0649-4)}{4-1}=0,0216
\end{aligned}
$$

Menghitung Consistency Ratio, dibutuhkan nilai RI yaitu Random Index yang didapat dari tabel Oarkridge ( $\mathrm{CR}=\mathrm{CI} / \mathrm{RI}$ ) Untuk n $=4$, nilai RI adalah 0,90. Jadi nilai $\mathrm{CR}$ untuk kriteria pemilihan mahasiswa berprestasi adalah $0,0216 / 0,90=0,024$. Penilaian 
perbandingan dikatakan konsisten jika CR tidak lebih dari 0,10, sehingga penilaian perbandingan kriteria pemilihan mahasiswa berprestasi sudah konsisten dan tidak memerlukan revisi penilaian.

\section{Simulasi Penentuan Ranking}

Pemilihan Mahasiswa Berprestasi Dengan Metode SAW

Setelah mendapatkan nilai bobot dari masing-masing kriteria dan dilakukan uji Consistency Ratio, maka langkah selanjutnya menentukan perankingan pemilihan mahasiswa berprestasi menggunakan metode Simple Additive Weighting (SAW). Proses penentuan ranking metode SAW adalah sebagai berikut :

A. Menentukan fungsi benefit (semakin tinggi nilainya semakin baik) atau fungsi cost (semakin rendah nilainya semakin baik) dari setiap kriteria pemilihan mahasiswa berprestasi, seperti terlihat pada tabel 9.

Tabel 9. Fungsi Kriteria Pemilihan Mahasiswa Berprestasi

\begin{tabular}{ccl}
\hline No & Kriteria & Fungsi \\
\hline 1 & IPK & Benefit $(+)$ \\
2 & Prestasi Akademik & Benefit $(+)$ \\
3 & Bahasa Inggris & Benefit $(+)$ \\
4 & Kepribadian & Benefit $(+)$ \\
\hline
\end{tabular}

B. Setelah diketahui fungsi benefir (+) dan fungsi cost (-) dari setiap kriteria seperti terlihat pada tabel 9, maka selanjutnya dilakukan perhitungan nilai dari masingmasing alternatif pada matrik awal seperti pada tabel 10 sehingga dihasilkan matrik normalisasi seperti terlihat pada tabel 11 dengan ketentuan sebagai berikut :

- Fungsi benefit (+) dihitung dengan rumus nilai pada cell dibagi dengan nilai max pada kolom.
- Fungsi cost (-) dihitung dengan rumus nilai min pada kolom dibagi nilai cell.

C. Setelah itu dilakukan perhitungan nilai setiap alternatif dengan cara melakukan perkalian dari hasil nilai matriks normalisasi setiap alternatif per kriteria dengan bobot per kriteria yang telah dihasilkan dari proses perhitungan metode AHP. Hasil perhitungan dapat dilihat pada tabel 8 .

Tabel 10. Matrik Awal Nilai Alternatif Mahasiswa Berprestasi

\begin{tabular}{ccccc}
\hline & \multicolumn{4}{c}{ Kriteria Mahasiswa Berprestasi } \\
\cline { 2 - 5 } Alternatif & IPK & $\begin{array}{c}\text { Prestasi } \\
\text { Akadem } \\
\text { ik }\end{array}$ & $\begin{array}{c}\text { Bahasa } \\
\text { Inggris }\end{array}$ & $\begin{array}{c}\text { Kepribadi } \\
\text { an }\end{array}$ \\
\hline Mhs 1 & 3.75 & 3 & 4 & 4 \\
Mhs 2 & 3.59 & 3 & 3 & 3 \\
Mhs 3 & 3.87 & 4 & 4 & 4 \\
Mhs 4 & 3.68 & 5 & 3 & 4 \\
Mhs 5 & 3.91 & 4 & 4 & 3 \\
Bobot & 0,07 & 0,19 & 0,31 & 0,43 \\
\hline
\end{tabular}

Tabel 11. Matrik Normalisasi Alternatif Mahasiswa Berprestasi

Kriteria Mahasiswa

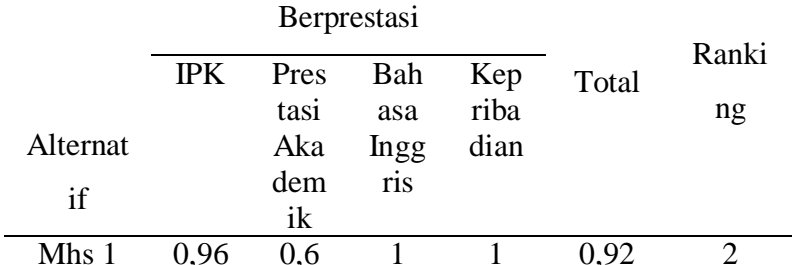

$\begin{array}{lllllll}\text { Mhs } 2 & 0,92 & 0,6 & 0,75 & 0,75 & 0,73 & 5\end{array}$

$\begin{array}{lllllll}\text { Mhs } 3 & 0,99 & 0,8 & 1 & 1 & 0,96 & 1\end{array}$

$\begin{array}{lllllll}\text { Mhs } 4 & 0,94 & 1 & 0,75 & 1 & 0,92 & 3\end{array}$

$\begin{array}{lllllll}\text { Mhs } 5 & 1 & 0,8 & 1 & 0,75 & 0,85 & 4\end{array}$

Bobot $\quad 0,07 \quad 0,19 \quad 0,31 \quad 0,43$ 
D. Berdasarkan simulasi di atas, maka mahasiswa 3 mendapatkan ranking 1, berarti mahasiswa 3 mendapat prioritas nomor 1 untuk terpilih menjadi mahasiswa berprestasi.

\section{Rancangan Layar Aplikasi SPK Mahasiswa Berprestasi}

Rancangan layar aplikasi Sistem Pendukung Keputusan mahasiswa berprestasi terdiri dari 9 rancangan sebagai berikut :

A. Rancangan Layar Menu Utama Rancangan layar ini digunakan untuk menampilkan menu utama dari aplikasi sistem pendukung keputusan mahasiswa berprestasi Akademi Sekretari Budi Luhur.

Akademi Sekretari Budi Luhur

Sistem Pendukung Keputusan

Pemilihan Mahasiswa Berprestasi

Gambar 2. Rancangan Layar Menu Utama

B. Rancangan Layar Login

Rancangan layar ini digunakan untuk masuk atau login kedalam aplikasi sistem pendukung keputusan mahasiswa berprestasi Akademi Sekretari Budi Luhur.

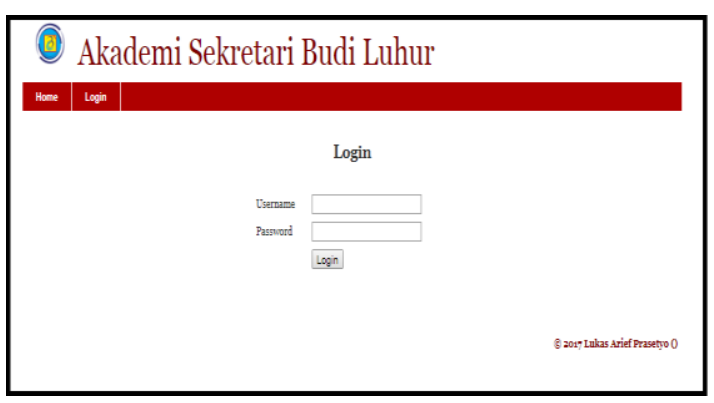

Gambar 3. Rancangan Layar Login

C. Rancangan Layar Sub Menu Master

Rancangan layar ini digunakan untuk menampilkan sub menu master dari aplikasi sistem pendukung keputusan mahasiswa berprestasi Akademi Sekretari Budi Luhur.

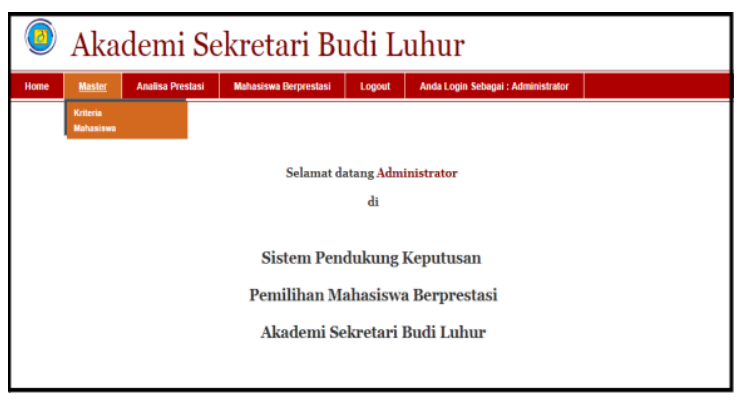

Gambar 4. Rancangan Layar Sub Menu Master

D. Rancangan Layar Sub Menu Analisa Prestasi

Rancangan layar ini digunakan untuk menampilkan sub menu Analisa Prestasi dari aplikasi sistem pendukung keputusan mahasiswa berprestasi Akademi Sekretari Budi Luhur.

Akademi Sekretari Budi Luhur

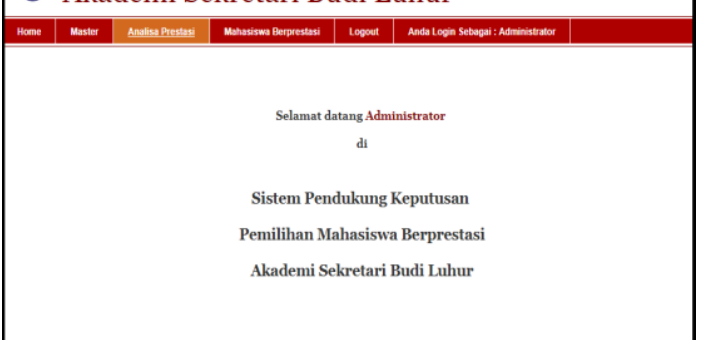

Gambar 5. Rancangan Layar Sub Menu Analisa Prestasi

E. Rancangan Layar Sub Menu Mahasiswa Berprestasi

Rancangan layar ini digunakan untuk menampilkan sub menu mahasiswa berprestasi dari aplikasi sistem pendukung keputusan mahasiswa berprestasi Akademi Sekretari Budi Luhur. 


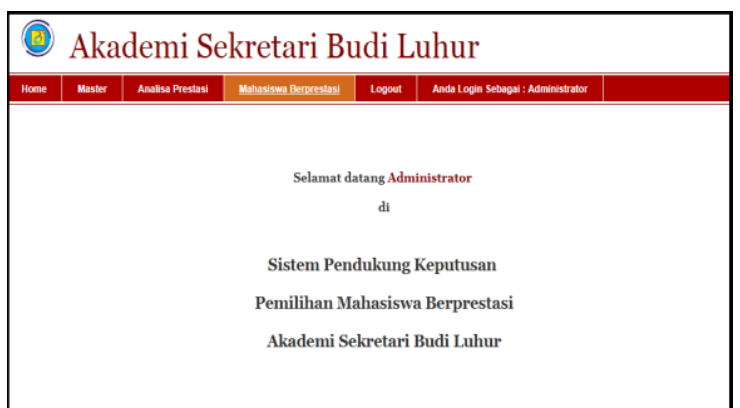

Gambar 6. Rancangan Layar Sub Menu Mahasiswa Berprestasi

F. Rancangan Layar Entry Kriteria Mahasiswa Berprestasi

Rancangan layar ini digunakan untuk menginput master kriteria mahasiswa berprestasi, dimana user akan menginput nama kriteria serta memilih apakah kriteria tersebut termasuk kategori benefit atau cost.

\section{Akademi Sekretari Budi Luhur}

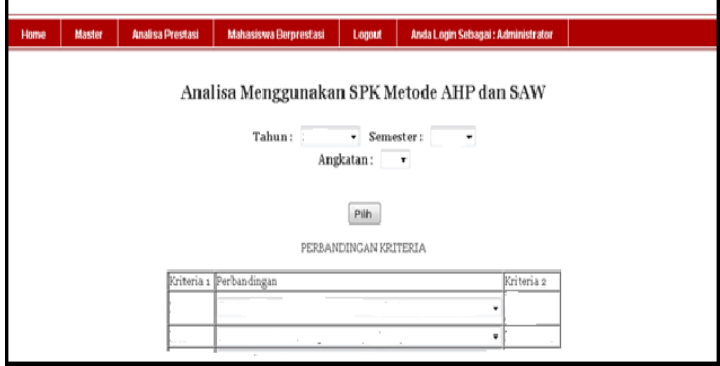

Gambar 7. Rancangan Layar Entry Kriteri Mahasiswa Berprestasi

G. Rancangan Layar Entry Kandidat Mahasiswa Berprestasi

Rancangan layar ini digunakan untuk menginput master mahasiswa yang akan menjadi kandidat mahasiwa berprestasi, dimana user menginput nim, nama dan peminatan.

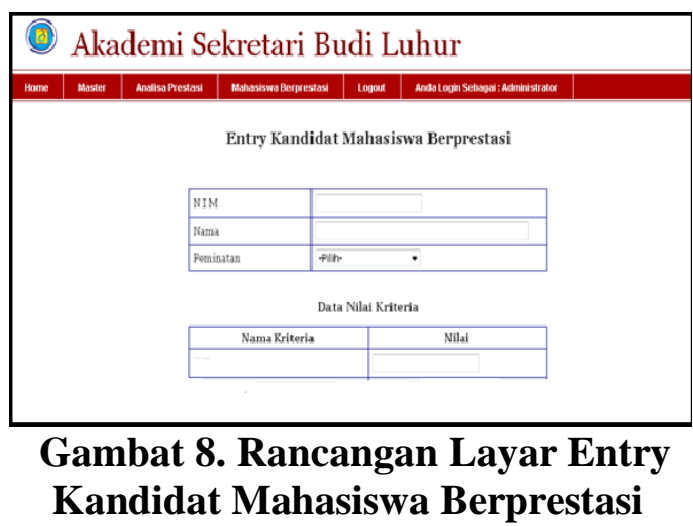

H. Rancangan Layar Entry Perbandingan Kriteria Mahasiswa Berprestasi.

Rancangan layar ini digunakan untuk menginput nilai perbandingan dari masing-masing kriteria mahasiswa berprestasi, diman user akan menginput atau memilih nilai perbandingan yaitu 1 sampai 9 atau $1 /(1-9)$.

Akademi Sẹkretari Budi Luhur

Tambah Data Kriteria

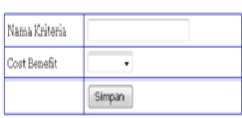

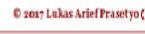

Gambar 9. Rancangan Layar Entry

Perbandingan Kriteria Mahasiswa Berprestasi

5. Rancangan Keluaran Aplikasi SPK Mahasiswa Berprestasi

Rancangan layar ini digunakan untuk mencetak laporan mahasiwa berprestasi yang terpilih per angkatan, dimana user akan menginput tahun ajaran dan semester. 


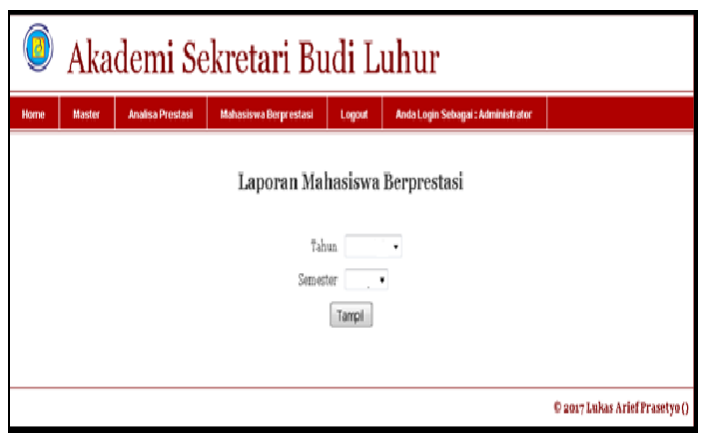

Gambar 10. Rancangan Keluaran Aplikasi SPK Mahasiswa Berprestasi

Pada tahap pengujian sistem peneliti menggunakan metode pengujian blackbox.

\begin{tabular}{|c|c|c|c|}
\hline No & Fungsi & Berhasil & Tidak \\
\hline 1 & $\begin{array}{lll}\text { Rancangan } & \text { Layar } & \text { Menu } \\
\text { Utama }\end{array}$ & $\sqrt{ }$ & \\
\hline 2 & Rancangan Layar Login & $\sqrt{ }$ & \\
\hline 3 & $\begin{array}{l}\text { Rancangan Layar Sub Menu } \\
\text { Master }\end{array}$ & $\sqrt{ }$ & \\
\hline 4 & $\begin{array}{l}\text { Rancangan Layar Sub Menu } \\
\text { Analisa Prestasi }\end{array}$ & $\sqrt{ }$ & \\
\hline 5 & $\begin{array}{l}\text { Rancangan Layar Sub Menu } \\
\text { Mahasiswa Berprestasi }\end{array}$ & $\sqrt{ }$ & \\
\hline 6 & $\begin{array}{lrr}\text { Rancangan } & \text { Layar } & \text { Entry } \\
\text { Kriteria } & \text { Mahasiswa } \\
\text { Berprestasi } & \end{array}$ & $\sqrt{ }$ & \\
\hline 7 & $\begin{array}{lr}\text { Rancangan } & \text { Layar } \quad \text { Entry } \\
\text { Kandidat } & \text { Mahasiswa } \\
\text { Berprestasi } & \end{array}$ & $\sqrt{ }$ & \\
\hline 8 & $\begin{array}{l}\text { Rancangan Layar Entry } \\
\text { Perbandingan } \\
\text { Mahasiswa Berprestasi. }\end{array}$ & $\sqrt{ }$ & \\
\hline 9 & $\begin{array}{l}\text { Rancangan Keluaran } \\
\text { Aplikasi SPK Mahasiswa } \\
\text { Berprestasi }\end{array}$ & $\sqrt{ }$ & \\
\hline
\end{tabular}

\section{SIMPULAN}

Dari pembahasan mengenai sistem pendukung keputusan untuk memilih mahasiswa berprestasi pada Akademi Sekretari Budi Luhur, maka dapat dihasilkan beberapa simpulan sebagai berikut :

1. Diharapkan sistem pendukung keputusan dengan menggunakan metode kombinasi Analytical Hierarchy Process (AHP) dan Simple Additive Weighting (SAW) dapat mempermudah Ketua Program Studi dalam menentukan atau memilih mahasiswa berprestasi.

2. Sistem pendukung keputusan mahasiswa berprestasi dengan menggunakan kriteria pedoman Dikti, 2016 dapat meminimalisir subjektifitas dalam menentukan mahasiswa berprestasi.

\section{DAFTAR PUSTAKA}

[1] Dikti. Pedoman Pemilihan Mahasiswa Berprestasi Program Diploma, Jakarta, 2016.

[2] Kusumadewi S, Purnomo, Hari. Aplikasi Lohika Fuzzy untuk Pendukung Keputusan. Yogyakarta: Graha Ilmu. 2010.

[3] Marimin, M. Aplikasi Teknik Pengambilan Keputusan Dalam Manajemen Rantai Pasok, Bogor: IPB Press. 2010.

[4] Tri Ferga Prasetyo, Chandra Kusumah. Sistem Pendukung Keputusan Mahasiswa Berprestasi Menggunakan Metode Analytical Hierarchy Process (AHP) (Studi Kasus: Universitas Majalengka), Jurnal J-Ensitec: Vol 02 No. 01, 2015 